\title{
State task for veterinary institutions: development, implementation and financial support
}

\author{
Ivan N. Nikitin, Mihail N. Vasiliev*, Aleksandr I. Akmullin, Elena N. Trofimova, and Viktoria A. Sapozhnikova
}

Kazan State Academy of Veterinary Medicine named after N. E. Bauman, Kazan 420029, Russia

\begin{abstract}
State budget-funded veterinary institutions are engaged in the development of state tasks for the state budget-funded veterinary institutions of the country by scientific institutions, executive authorities of the subjects of the Russian Federation in the field of veterinary medicine, heads of large state veterinary institutions for about 10 years. Development and implementation of state tasks is carried out in all 85 subjects of the Russian Federation. Approaches to the procedure for their preparation, implementation and financial support are periodically improved. Scientific research on the creation of a regulatory framework for the establishment of a scientifically sound list of state veterinary services, the procedure for determining the volume of such services, and the calculation of the financial support for the implementation of state tasks are being intensively conducted. The result of such research in the N.E. Bauman Kazan State Academy of Veterinary Medicine was the development of the "Recommendations on the formation of the state assignment for the provision of public services (works) to institutions of the State Veterinary Service of the Russian Federation", which were approved by the Scientific and Technical Council of the Ministry of Agriculture of the Russian Federation on June 11, 2014.
\end{abstract}

\section{Introduction}

Research in the field of veterinary services is carried out both in our country and abroad [1-5]. In particular, the scientific development of the methodology for the formation of the state task to the institutions of the state veterinary service began in 2009, when the direct financing of the activities of the state veterinary institutions was terminated due to the introduction of appropriate amendments to the Budget Code of the Russian Federation (Articles 69; 69.1; 69.2)and the Federal Law "On Non-Commercial Organizations", the adoption of the Resolution of the Government of the Russian Federation "On the Procedure of Formation of the Government Assignment in Respect of Federal State Institutions and Financial Support for the Performance of the Government Assignment", the approval of the "Methodological Recommendations for Calculation of Normative Expenses for the Provision of Regulatory Services by Federal State Institutions for the Provision of Regulatory Expenses for the Maintenance of the Property of Federal State Institutions" by the Ministry of Finance of the Russian Federation [6].

\section{Materials and methods}

Research on the development of state tasks and the calculation of financial support for their implementation were carried out on behalf of the Department of Veterinary Medicine of the Ministry of Agriculture of the Russian Federation, as well as the executive authorities in the field of veterinary medicine of the Republics of Tatarstan, Udmurt Republic, Buryatia, Khabarovsk Territory, Voronezh, Leningrad, Lipetsk, Kaliningrad regions in 2008-2015.

When developing the "Recommendations on the formation of the state task for the provision of state services (performance of work) to institutions of the State Veterinary Service of the Russian Federation" were guided by the Budget and Labor Codes of the Russian Federation, the Laws of the Russian Federation "On Non-Commercial Organizations", "On Veterinary Medicine", the Resolution of the Government of the Russian Federation of September 2, 2010. "On the procedure of formation of the state task in respect of federated state institutions and financial support of the state task performance", relevant recommendations of the Ministry of Finance of the Russian Federation, the Ministry of Economic Development of the Russian Federation, regional normative legal acts on the procedure of generation and financial support of the state task performance, methods of diagnostics, prophylaxis of infectious and invasive animal diseases and other normative legal acts.

\section{Research results}

In 2009-2014, a draft of federal recommendations on the formation of the state assignment for the provision of state services (work) by the institutions of the State

\footnotetext{
* Corresponding author: mnvasiliev@ mail.ru
} 
Veterinary Service of the Russian Federation was developed, which include:

- methods of determination of normative expenses for rendering state services (performance of works): normative, structural, expert;

- the procedure for determining the standard costs of providing public services (performance of works);

- the procedure for determining the standard costs of maintaining the property of state veterinary institutions;

- structure of the state assignment of budgetary institutions of the State Veterinary Service of the Russian Federation.

The recommendations were examined by the Ministry of Economic Development of the Russian Federation, the Department of Law of the Ministry of Agriculture of the Russian Federation, the Federal Legal Center of Agricultural Complex, the Departments of Veterinary Medicine of the Novosibirsk Region, Khabarovsk Territory, the Committee of Veterinary Medicine of the Volgograd Region, the Main Department of Veterinary Medicine of the Moscow Region and approved by the Scientific and Technical Council of the Ministry of Agriculture of the Russian Federation on June 11, 2014[7].

One of the examples of practical implementation of the recommendations on the formation of the state task was the development of the draft state task for the state veterinary institutions of the Voronezh region in 2012.

The following are presented in the state assignment:

- list of regulatory documents that guided the development of the state assignment;

- methodology for establishing the costs of public services;

- register of state veterinary services;

- list of state veterinary institutions providing state services;

- extract from the register of expenditure obligations;

- consumers of state veterinary services;

- volumes of state assignment (presented in Table 1);

- indicators characterizing the quality of state veterinary services rendered;

- maximum prices (tariffs) for payment for state veterinary services;

- procedure of control over the performance of state veterinary services, state assignment;

- requirements for reporting on the performance of the state assignment.

It is established that the planned amount of funds required to fulfill the state assignment for 2012 decreased by $3.9 \%$. In the structure of the planned volume of financial support for the execution of the state assignment for 2012, the cost of anti-epizootic measures amounted to $56.6 \%$, veterinary and sanitary expertise 22.9, unforeseen work - 9.1, laboratory research - 8.1, the work of the epizootic group - 2.1, the work of the State Institution "Regional Veterinary Station" - 1.1\%.
Table 1. Volumes of state assignment to institutions of the State Veterinary Service of the Voronezh region

\begin{tabular}{|l|c|c|}
\hline \multirow{2}{*}{\begin{tabular}{c}
\multirow{2}{*}{$\begin{array}{c}\text { Types of public } \\
\text { services }\end{array}$} \\
\cline { 2 - 3 }
\end{tabular}} & \multicolumn{2}{|c|}{$\begin{array}{c}\text { Cost of state veterinary } \\
\text { services, million rubles. }\end{array}$} \\
\cline { 2 - 3 } & 2011 & $\begin{array}{c}\text { actual for } \\
2012\end{array}$ \\
\hline Epizootic measures & 98.5 & 94.4 \\
\hline $\begin{array}{l}\text { Veterinary-sanitary } \\
\text { inspection }\end{array}$ & 39.8 & 38.3 \\
\hline Laboratory research & 14.1 & 13.6 \\
\hline $\begin{array}{l}\text { Regional Veterinary } \\
\text { Station }\end{array}$ & 2.0 & 1.9 \\
\hline $\begin{array}{l}\text { The work of the } \\
\text { epizootic unit }\end{array}$ & 3.6 & 3.5 \\
\hline Unforeseen works & 15.8 & 15.2 \\
\hline In total: & 173.8 & 166.9 \\
\hline
\end{tabular}

Table 2. Volumes of the state task to institutions of the State Veterinary Service of the Lipetsk region

\begin{tabular}{|l|c|c|}
\hline \multirow{2}{*}{$\begin{array}{c}\text { Types of public } \\
\text { services }\end{array}$} & \multicolumn{2}{c|}{$\begin{array}{c}\text { Cost of state veterinary } \\
\text { services, million rubles. }\end{array}$} \\
\cline { 2 - 3 } & $\begin{array}{c}\text { actual for } \\
2012\end{array}$ & $\begin{array}{c}\text { planned for } \\
2013\end{array}$ \\
\hline Antiepizootic measures & 78.2 & 87.7 \\
\hline $\begin{array}{l}\text { Medical and preventive } \\
\text { measures }\end{array}$ & 2.0 & 2.2 \\
\hline $\begin{array}{l}\text { Veterinary and sanitary } \\
\text { inspection }\end{array}$ & 21.2 & 23.7 \\
\hline $\begin{array}{l}\text { Veterinary and sanitary } \\
\text { measures }\end{array}$ & 28.1 & 31.5 \\
\hline $\begin{array}{l}\text { Treatment of animals } \\
\text { with infectious, } \\
\text { invasive and non- } \\
\text { communicable diseases }\end{array}$ & 138.6 & 155.2 \\
\hline Organizational work & 13.1 & 14.6 \\
\hline $\begin{array}{l}\text { Laboratory research, } \\
\text { including: }\end{array}$ & 60.7 & 68.0 \\
\hline $\begin{array}{l}\text { - bacteriological } \\
\text { research }\end{array}$ & 19.6 & 22.0 \\
\hline $\begin{array}{l}\text { - zoological hygiene } \\
\text { research }\end{array}$ & 3.6 & 4.0 \\
\hline - virological research & 8.9 & 10.0 \\
\hline - serological research & 4.2 & 4.6 \\
\hline - PCR diagnostics & 9.5 & 10.6 \\
\hline - radiological research & 0.75 & 0.84 \\
\hline - biochemical research & 0.1 & 0.11 \\
\hline - organizational works & 14.2 & 15.9 \\
\hline Unforeseen work & 17.1 & 19.1 \\
\hline Total & 358.9 & 402.1 \\
\hline
\end{tabular}

The second example of the formation of the State task for state institutions of the region's veterinary medicine is the project developed by us for the Lipetsk region. Here, a different approach to the classification of state veterinary services is noted and, based on the planned volumes of public services, the amount of funds needed to fulfill the state task for 2013 increased by $12.0 \%$. 
In the structure of the planned volume of financial support for fulfilling the state task for this year, the costs of antiepizootic measures amounted to $21.8 \%$, medical and preventive measures -0.6 , veterinary and sanitary inspection -5.9 , veterinary and sanitary measures -7.8 , treatment of animals with infectious, invasive and noncommunicable diseases - 38.6, organizational work 3.6, laboratory research -16.9 , unforeseen work $-4.8 \%$.

In the process of implementation of the state assignment in the regions the planned scope of work was completed in full, in a timely manner and with high quality. The stability of financial support is ensured, which is one of the foundations of effective work [6], as well as reliable prevention of infectious and invasive animal diseases.

Table 3 presents the volumes of financial support of the state task of 8 subjects of the Russian Federation.

Table 3. Volumes of financial support of the state assignment of the institutions of the State Veterinary Service of individual constituent entities of the Russian Federation

\begin{tabular}{|l|c|c|c|c|}
\hline & Calculati & \multicolumn{3}{|c|}{$\begin{array}{c}\text { Volumes of financial support } \\
\text { of the state assignment: }\end{array}$} \\
\cline { 4 - 6 } $\begin{array}{c}\text { Name of the } \\
\text { subject of the } \\
\text { Russian } \\
\text { Federation }\end{array}$ & $\begin{array}{c}\text { on period } \\
\text { of the } \\
\text { state's } \\
\text { mission, } \\
\text { year }\end{array}$ & $\begin{array}{c}\text { in } \\
\text { absolute } \\
\text { terms, } \\
\text { million } \\
\text { rubles. }\end{array}$ & $\begin{array}{c}\text { per head } \\
\text { of cattle, } \\
\text { rub. }\end{array}$ & $\begin{array}{c}\text { per 1 } \\
\text { km }^{2} \text { of } \\
\text { the } \\
\text { subject's } \\
\text { territory, } \\
\text { rub. }\end{array}$ \\
\hline $\begin{array}{l}\text { Udmurt } \\
\text { Republic }\end{array}$ & 2009 & 189.2 & 492.0 & 4498.7 \\
\hline $\begin{array}{l}\text { Republic of } \\
\text { Tatarstan }\end{array}$ & 2011 & 244.2 & 223.6 & 3599.9 \\
\hline $\begin{array}{l}\text { Voronezh } \\
\text { region }\end{array}$ & 2012 & 166.9 & 395.9 & 3196.5 \\
\hline Lipezk region & 2013 & 402.1 & 3201.2 & 16720.2 \\
\hline $\begin{array}{l}\text { Khabarovsk } \\
\text { Region }\end{array}$ & 2013 & 187.2 & 7641.6 & 237.7 \\
\hline $\begin{array}{l}\text { Leningrad } \\
\text { region }\end{array}$ & 2015 & 329.8 & 1815.0 & 3930.3 \\
\hline $\begin{array}{l}\text { Republic of } \\
\text { Buryatia }\end{array}$ & 2015 & 210.3 & 557.6 & 598.7 \\
\hline $\begin{array}{l}\text { Kaliningrad } \\
\text { region }\end{array}$ & 2016 & 171.8 & 1490.3 & 11360.7 \\
\hline
\end{tabular}

Different volumes of financial support are assumed depending on the level of development of the agroindustrial complex, as well as the economic situation in a particular region of the country.

The largest amount of subsidies for the execution of the state task was assumed in the process of its formation for the institutions of the State Veterinary Service of the Lipetsk region in 2013 in the amount of 402.1 million rubles, followed by the Leningrad region, the Republics of Tatarstan, Buryatia, Udmurt Republic, Khabarovsk Territory and Kaliningrad region. The lowest amount of financing was assumed for the Voronezh region in 2012 - 166.9 million rubles, which is only $41.5 \%$ of the Lipetsk region.
One of the fundamental factors influencing the development of veterinary service in the constituent entities of the Russian Federation is the number of cattle in the region [8].

The comparative analysis of the obtained indicators, taking into account the number of cattle in the analyzed subjects of the Russian Federation at the end of the calculation period of the state assignment, the Khabarovsk Region ranks first in terms of funding, where one head of cattle accounts for 7.64 thousand rubles, followed by the Lipetsk, Leningrad, Kaliningrad, Buryatia, Udmurt Republic, and Voronezh regions, with the Republic of Tatarstan having the highest number of analyzed subjects of the Russian Federation (223.6 rubles).

The comparative analysis of the obtained indicators of the volume of financing of the state assignments of the State Veterinary Service of the subjects of the Russian Federation, taking into account the area occupied by the region, can be divided into 3 groups.

The first group is the regions where less than 1.0 thousand rubles of financing of the state task falls on the basis of $1 \mathrm{~km}^{2}$ of area (Khabarovsk Territory - 237.7 rubles, the Republic of Buryatia - 598.7 rubles). These regions stand out against the background of other large occupied territories.

The second group, the most numerous, is the regions, where 3.2 thousand to 4.5 thousand rubles of financing of the state assignment per $1 \mathrm{~km}^{2}$ of area (the Voronezh Oblast, the Republic of Tatarstan, the Leningrad Oblast and the Udmurt Republic) fall within this group. The third group is the regions where per $1 \mathrm{~km}^{2}$ of area there are more than 11.0 thousand rubles of financing of the state assignment (Kaliningrad Region - 11.4 thousand rubles, Lipetsk Region - 16.7 thousand rubles), these regions have the minimum area among the analyzed subjects of the Russian Federation.

One of the stages of the research was the study of the order of formation of the state assignment in the Republic of Tatarstan, Mari-El, Udmurt Republic in 2017. It should be noted that these subjects have different needs in state veterinary services. The analysis of the state budget-funded veterinary institutions of the regions shows that they have achieved the planned values for the provision of state services.

The volume of financial support of the state assignment of the State Veterinary Service of the Republic of Tatarstan for 2015 was equal to that of the State Veterinary Service of the Republic of Tatarstan. 286.9 million rubles, 2016 - 302.0 million, 2017 - 308.2 million rubles. The increase in financing of government assignments in 2016 was $5.3 \%, 2017-2.1 \%$.

In the Udmurt Republic, the volume of financial support for the state task for 2015 was equal to - 227.0 million rubles, 2016 - 238.2 million, 2017 - 277.6 million rubles. The increase in financing of government assignments in 2016 amounted to $4.9 \%, 2017$. - - 16,5\%.

The basis for calculating state assignments in these regions was the state assignments developed by the Department of Veterinary Administration of the N.E. Bauman Kazan State Academy of Veterinary Medicine in the Republic of Tatarstan for 2011, Udmurt Republic - 
2009. Over the past period, by 2015, the volume of financial support of the state assignment in Tatarstan increased by $17.5 \%$, and in the Udmurt Republic - by $20.0 \%$.

In the Republic of Mari-El, the volume of financial support for the state task of the state veterinary service institutions was equal to 2015. - 117.2 million rubles, 2016 - 107.4 million, 2017 - 117.6 million rubles. The decrease in financing in 2016 was $8.4 \%$, and in 2017 it increased by $9.5 \%$ to a level slightly above 2015 .

State tasks in the Republic were formed by the Veterinary Committee of the region independently. Fig. 1 shows the data by region.

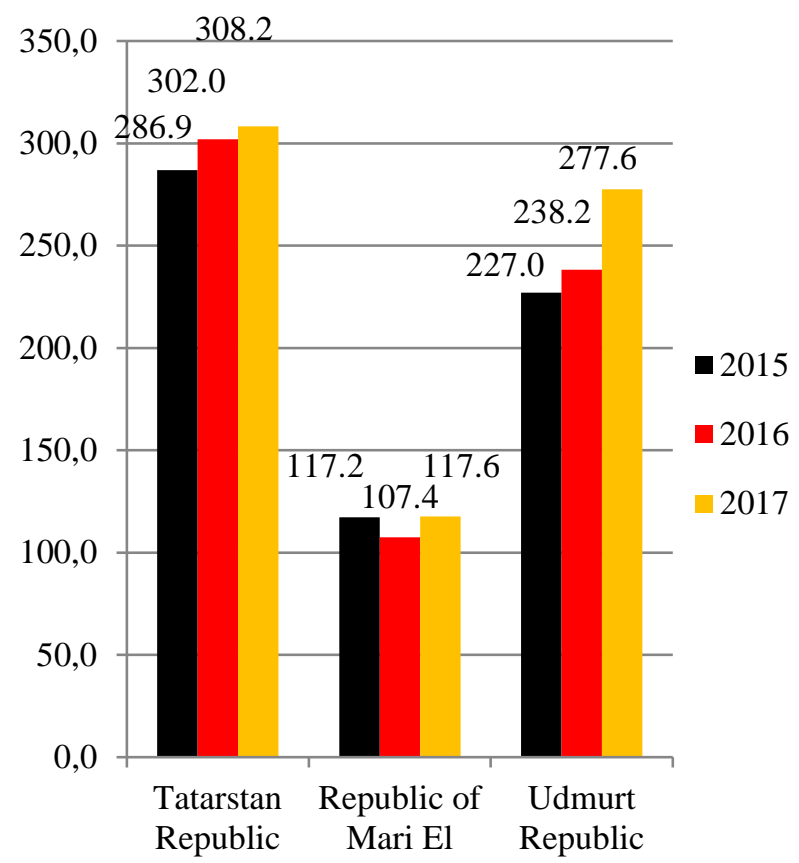

Fig. 1. Volumes of financing of state assignments of the State Veterinary Service of the Republics of Tatarstan, Mari-El, Udmurt Republic, million rubles.

\section{Conclusion}

State tasks are the main activity of the state budgetfunded veterinary institutions of the Russian Federation $[6,7,9,10]$. Using the results of scientific research of the Department of Organization of Veterinary Affairs of the Kazan State Academy of Veterinary Medicine named after N.E. Bauman, we have developed 8 draft state tasks for institutions of the State Veterinary Service of the regions of the Russian Federation (Khabarovsk
Territory; Voronezh, Kaliningrad, Leningrad, Lipetsk Regions; Republics of Buryatia, Tatarstan, Udmurtia) for 2009 - 2016.

All drafts of state assignments are used by the founders as a document justifying the volume of financial support of state assignments of these institutions. The work carried out allowed the institutions of the State Veterinary Service of the Russian Federation to receive sufficient funding for mandatory antiepizootic measures and other work carried out by them as the main activity in accordance with the state assignment and in the interests of the state and society.

Thanks to the experience gained in the development of draft state assignment to the institutions of the State Veterinary Service of the Russian Federation, the "Recommendations on the formation of the state assignment for the provision of state services (work) by the institutions of the State Veterinary Service of the Russian Federation", as well as the "Recommended list of veterinary services (work) included in the state assignment for the provision of state services (work) by budgetary (public) institutions of the State Veterinary Service of the Russian Federation.

\section{References}

1. C. De Haan, D.L. Umali, Public and Private Roles in Agricultural Development In Proc. of 12th Agricultural Sector symposium The World Bank 76, 125-137 (1992)

2. H. Hannah, J. of the American Veterinary Medical Association 207, 576-577 (1995)

3. S. McKay, Irish Veterinary J. 61, 188-189 (2008)

4. S. McKay, Irish Veterinary J. 61, 262-263 (2008)

5. G. Snyder, DVM: The Newsmagazine of Veterinary Medicine 40, 62-64 (2009)

6. I.N. Nikitin, M.N. Vasiliev, Veterinary science 5, 1618 (2013)

7. S.G. Dresviannikova, I.N. Nikitin, E.N. Trofimova, M.N. Vasiliev, Veterinary regulatory issues 3, 40-45 (2015)

8. K.A. Komarova, Science News: Problems and Prospects 2-2(61), 53-56 (2016)

9. A.V. Leshtaeva, Veterinary Pathology 1, 74-78 (2010)

10. A.A. Uvarov, State and Law 2, 115-117 (2012) 